\title{
Relative Income Traps
}

Maria A. Arias and Yi Wen

Despite economic growth in the post-World War II period, few developing countries have been able to catch up to the income levels in the United States or other advanced economies. Such countries remain trapped at a relative low- or middle-income level. In this article, the authors redefine the concept of income traps as situations in which income levels relative to the United States remain constantly low and with no clear sign of convergence. This approach allows them to study the issue of economic convergence (or lack of it) directly. The authors describe evidence pointing to the existence of both relative low- and middle-income traps and examine cross-country historical transitions between income groups at the global and regional levels. Finally, they point out challenges to the benchmark neoclassical growth theory, which predicts convergence to the developed world over time, and discuss existing theories with the potential to explain income traps. (JEL E13, L52, O11, O47)

Federal Reserve Bank of St. Louis Review, First Quarter 2016, 98(1), pp. 41-60.

Maria A. Arias is a senior research associate at the Federal Reserve Bank of St. Louis. Yi Wen is an assistant vice president and economist at the Federal Reserve Bank of St. Louis and professor of economics in the School of Economics and Management at Tsinghua University. The authors thank Stephen Williamson, Juan Sánchez, and Ana Maria Santacreu for helpful comments.

(c) 2016, Federal Reserve Bank of St. Louis. The views expressed in this article are those of the author(s) and do not necessarily reflect the views of the Federal Reserve System, the Board of Governors, or the regional Federal Reserve Banks. Articles may be reprinted, reproduced, published, distributed, displayed, and transmitted in their entirety if copyright notice, author name(s), and full citation are included. Abstracts, synopses, and other derivative works may be made only with prior written permission of the Federal Reserve Bank of St. Louis. 
tries have the same access to the world frontier technologies. ${ }^{2}$ But very few low- or middleincome countries have successfully caught up to high-income countries.

Per capita income in many poor countries is 30 to 50 times lower than that of the United States and sometimes even lower (i.e., less than $\$ 1,000$ per year). ${ }^{3}$ It may take at least 170 to 200 years for such countries to catch up to U.S. living standards, assuming that the poor countries could maintain a growth rate consistently 2 percentage points above the U.S. rate (about 3 percent per year on average). Such growth would be difficult, if not impossible. It is even harder to imagine that such countries can reach U.S. living standards within one or two generations (40 to 50 years), similar to how North American and Western European economies caught up to Britain during the 1800s after the Industrial Revolution. To achieve that speed of convergence today, developing countries would need to grow about 8 percentage points faster than the United States (or about 11 percent per year) nonstop for 40 to 50 years. In recent history, only China has come close to this growth rate; it maintained a 10 percent annual growth rate (7 percentage points above the U.S. rate) for 35 years, but per capita income was still only one-seventh of that in the United States in 2014. Hence, the lack of income convergence and relative income traps appear to be real problems.

We begin this article with a brief review of various definitions of "income traps" extant in the literature. Then, we redefine the concept using a relative income measure and describe evidence pointing to the existence of both low- and middle-income traps. We continue with a more in-depth analysis of the income traps by finding episodes of rapid and persistent relative growth and use them to assess the relationship between relative growth and several macroeconomic variables. To test the existence of income traps based on our new definition, we examine cross-country historical transitions between income groups using different time horizons and look at regional transition patterns to discern possible regional-specific effects. Finally, we discuss possible explanations for why some countries or regions remain trapped at a relatively low- or middle-income level while others have escaped the traps and continued to grow at a rate faster than the United States.

\section{A BRIEF LITERATURE REVIEW}

The literature on economic development provides various ways to classify countries by income groups. In addition, definitions of the "poverty trap" and the "middle-income trap"4 can be based on subjectively defined rules of thumb, statistical approaches to find structural breaks in the time series, or a combination of both (Kar et al., 2013).

For example, Eichengreen, Park, and Shin $(2012,2013)$ used per capita gross domestic product (GDP) in constant international purchasing power parity ( $\mathrm{PPP}$ ) prices to analyze the frequency and correlates of growth slowdowns in fast-growing middle-income countries. They use an approach similar to that used by Hausmann, Pritchett, and Rodrick (2005) to identify and analyze growth accelerations. Aiyar et al. (2013) used growth slowdowns to define a middle-income trap as a large sudden and sustained deviation from the growth path predicted by a basic conditional convergence framework. Felipe (2012) took a different approach and defined the traps in terms of the median number of years it took countries already in the 
high-income category in 1950 to transition from lower middle-income to upper middleincome and then to high-income status using GDP per capita in international dollars and the World Bank's income thresholds to define the income groups in analyzing these historical income transitions.

The body of this literature has mainly focused on using absolute measures of income levels or growth rates to characterize income gaps or to measure low- and middle-income traps. But in doing so, this literature has ignored the more pervasive phenomenon of a lack of convergence. That is, a country's income level can grow permanently in absolute terms but nonetheless remain permanently below the U.S. level, trapped at a lower relative income level because its growth rate is lower than or equal to the U.S. rate.

Few articles have explored the problem from the viewpoint of relative income. For example, Im and Rosenblatt (2013) surveyed the empirical evidence for different relative and absolute definitions of middle-income traps, describing the approaches used to measure both absolute and relative income thresholds in the literature.

\section{REDEFINING THE INCOME TRAP}

Although many so-called low- or middle-income countries have experienced persistent economic growth, their growth rates have never surpassed the U.S. growth rate. Consequently, these countries have been unable to close their income gaps with the United States. In other words, they remain "trapped" at relatively lower income levels compared with the living standards of the developed countries, contrary to the neoclassical growth theory's predictions that they will converge because of technology spillover and international capital flows. ${ }^{5}$

The lack of relative income convergence implies that U.S. per capita income, as well as general living standards, will continue to be 10 to 50 times higher than in low-income economies and two to five times higher than in middle-income economies. Moreover, the lack of a clear and consistent definition of low- and middle-income traps or a standard approach to measure and test the theory hinders the ability to easily (i) compare the results obtained across studies and (ii) assess the validity of possible explanations behind the income trap phenomenon.

Therefore, redefining the low- and middle-income traps as situations in which income levels relative to those of the United States remain constantly low and with no clear sign of convergence allows us to study the issue of economic convergence (or lack of it) more directly. Specifically, we use income relative to that of the United States as our reference point to study the failure of developing countries to achieve the same status as their developed counterparts.

This relative income gap perspective is important because the economies of even the poorest countries continue to grow at some positive rate every year. Easterly (2006) noted that relative growth is not significantly different across income quintiles over an extended period, but unless lower-income economies grow more rapidly and persistently than developed countries, they will not be able to catch up.

Such a permanent relative income gap has important welfare implications. Although Lucas (2000) points out that it is the growth rate that matters the most for welfare, a persistent 
income gap also matters greatly. As John Stuart Mill keenly observed, "men do not desire to be rich, but richer than other men." 6 In particular, based on micro-level household data, Luttmer (2005) found that, controlling for their own income, individuals reported lower levels of happiness when their neighbors' income was known to be higher.

\section{Data}

We use real GDP data at chained PPP rates from the Penn World Table version 8.0 (PWT 8.0) to calculate income relative to the United States for a sample of 107 countries between 1950 and 2011. ${ }^{7}$ We first aggregate the ratio of total real GDP relative to that of the United States for each year into six regions: Africa, Asia (excluding the Tigers, China, and Japan), Asian Tigers (including China and Japan), Eastern Europe, Latin America, and member countries of the Organisation for Economic Co-operation and Development (OECD). This regional aggregate of relative income is used to identify episodes of rapid and persistent relative growth, as described below. Table 1 lists the countries in the sample for each region.

To analyze the relationship between the relative growth regimes and broader macroeconomic variables, we use a measure of gross trade (the share of exports and imports relative to GDP), the value of terms of trade, and the share of investment relative to GDP, all obtained from the PWT 8.0. Moreover, following Buera, Monge-Naranjo, and Primiceri (2011), we use a proxy for market orientation calculated as the percentage of countries in the region that are open to trade during any given year, based on the index of trade openness calculated by Sachs and Warner (1995) and expanded by Wacziarg and Welch (2008).

Using the PWT 8.0 ratio of real GDP per capita relative to the United States for each country in the sample, we analyze the income transitions between groups and test the income trap hypothesis. Finally, we check the robustness of these results by repeating the income transition analysis using the ratio of real GDP per capita relative to the United States ${ }^{8}$ with data from the 2013 version of the Maddison-Project (Bolt and Van Luiden, 2013). Overall, there are data for 104 of the 107 countries in our sample; for many of them the data go as far back as 1870 .

\section{Stylized Facts}

The most common examples of rapid and persistent relative income growth (leading to convergence) are the Asian Tigers (Hong Kong, Singapore, South Korea, and Taiwan); other examples include countries such as Spain and Ireland. Figure 1 shows a sample of these economies whose relative per capita income grew significantly faster than that of the United States. The faster growth began in the late 1960s and continued through the early 2000s, catching up or converging to the higher level of U.S. per capita income. In sharp contrast, per capita income relative to the United States remained constant and stagnant-between 10 percent and 40 percent of U.S. income-in the Latin American countries listed in the figure. Despite their moderate absolute growth during the same period, these countries remain stuck in the relative middle-income trap and show no sign of convergence to higher income levels.

The lack of convergence is even more striking among low-income countries (Figure 2). For example, Bangladesh, El Salvador, Mozambique, and Nepal are stuck in a poverty trap, 


\section{Table 1}

\section{Countries by Region}

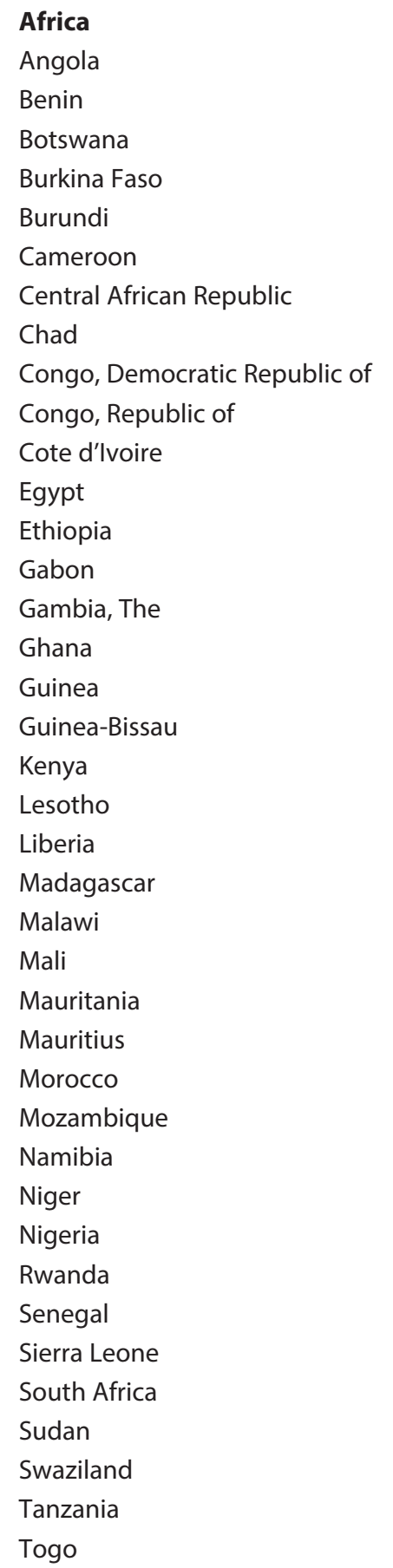

Africa, cont'd

Tunisia

Uganda

Zambia

Zimbabwe

\section{Asia (excluding Tigers)}

Bangladesh

Cambodia

India

Indonesia

Laos

Malaysia

Mongolia

Nepal

Pakistan

Philippines

Sri Lanka

Thailand

Vietnam

\section{Asian Tigers}

China

Hong Kong

Japan

Korea, Republic of

Singapore

Taiwan

\section{Eastern Europe}

Albania

Bulgaria

Hungary

Poland

Romania

Turkey

\section{Latin America}

Argentina

Bolivia

Brazil

Chile

Colombia

Costa Rica

Dominican Republic

Ecuador

El Salvador

Guatemala

Honduras

Jamaica

Mexico

Panama

Paraguay

Peru

Trinidad \& Tobago

Uruguay

Venezuela

\section{OECD}

Australia

Austria

Belgium

Canada

Denmark

Finland

France

Germany

Greece

Ireland

Israel

Italy

Netherlands

New Zealand

Norway

Portugal

Spain

Sweden

Switzerland

United Kingdom 


\section{Arias and Wen}

\section{Figure 1}

\section{Middle-Income Trap}

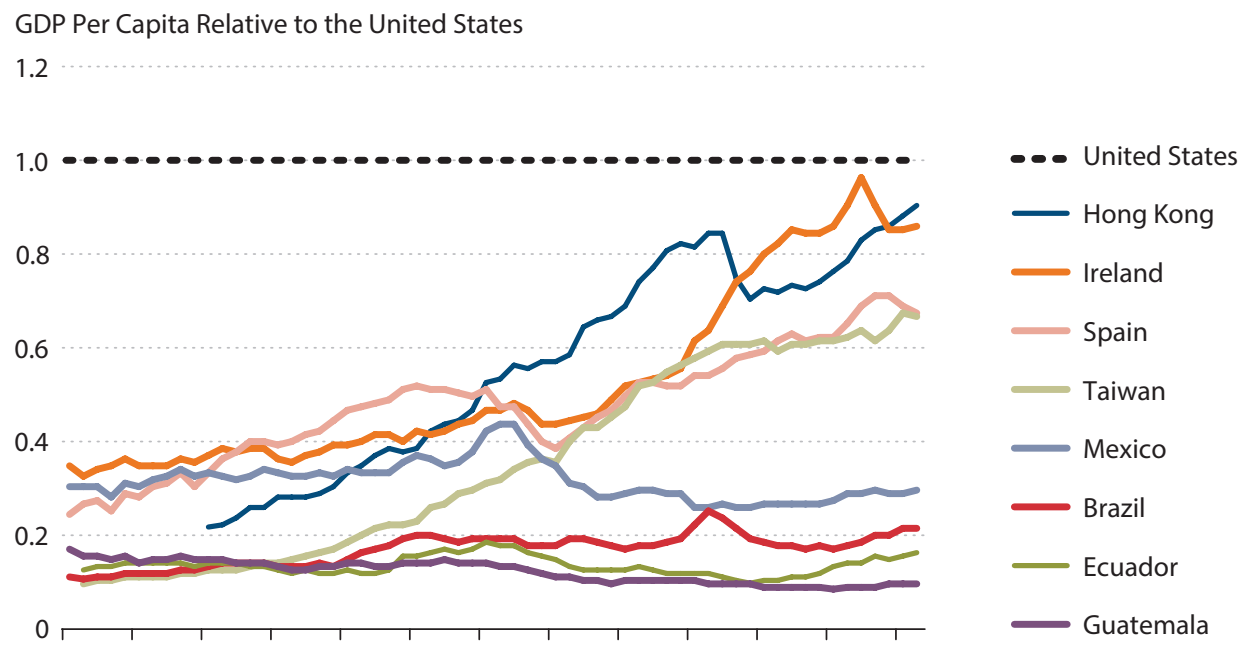

SOURCE: PWT 8.0 and authors' calculations.

\section{Figure 2}

\section{Low-Income Trap}

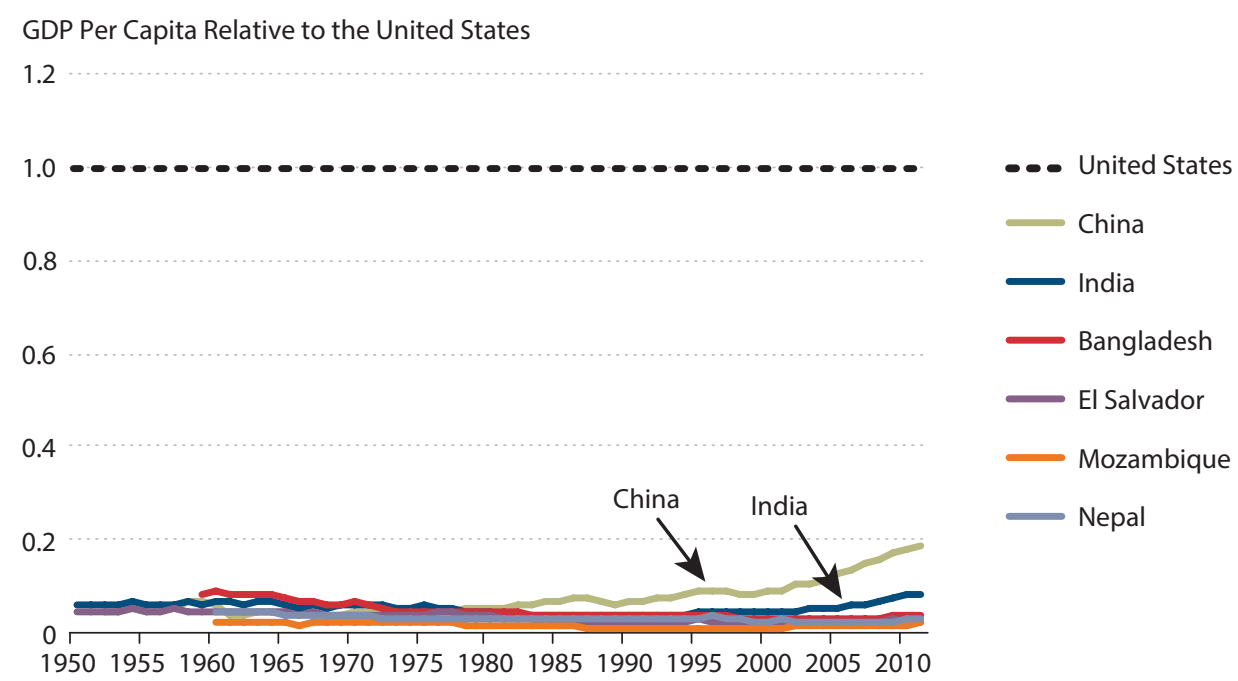

SOURCE: PWT 8.0 and authors' calculations. 
where their relative per capita income is constant at or below 5 percent of the U.S. level. Even though their economies might have grown moderately in absolute terms, they have not grown at a rate faster than the U.S. growth rate; thus, their relative income levels have not increased. As a result, the income gap between these nations and the United States has permanently been at least 20 times their own per capita incomes.

In comparison, China's economy has grown relatively faster than the U.S. economy since about the early 1980s, breaking away from the relative low-income trap and reaching middle per capita income levels. India has also shown signs of escaping the low-income trap since the early 1990s. However, both countries still have a long way to go to catch up to and converge to the levels in developed economies, and both have yet to encounter the relative middle-income trap. ${ }^{9}$

\section{CORRELATES OF GROWTH}

What potential factors could contribute to (or explain) the relative income traps? Causal explanation is difficult in a statistical framework unless good instrumental variables are available, but this is not the case at the moment. In this section, we conduct a correlation analysis.

Specifically, we start with a filter-based approach to identify episodes of rapid and persistent relative growth using the following criteria. Relative growth episodes must be at least five years long with at least four periods of rapid growth, where rapid growth is defined as relative growth higher than 1 percent for non-OECD countries and 0.5 percent for OECD countries (considering that the United States has grown at an average rate of about 2 percent since 1950). Once a start date for the growth regime is found, the last date is defined at the next relative growth peak, allowing for several years of slow or negative relative growth. The shaded areas in Figure 3 represent the relative growth episodes as determined by our algorithm.

This approach relaxes the regime length constraints set in other filter-based algorithms (e.g., Eichengreen, Park, and Shin, 2012, 2013; and Aiyar et al., 2013), allowing us to create a dichotomous variable that identifies the entire length of the growth regime, analogous to a variable created with a statistical model such as the Bai-Perron methodology to find structural breaks in the time series (e.g., Jones and Olken, 2008).

Then, we examine the cross-sectional correlation between average economic growth during the growth regimes and several macroeconomic variables based on the following model:

$$
\Delta \ln y_{i}=\ln x_{i}+u
$$

where $y_{i}$ in equation (1) is the average relative income ratio during each regime; $x_{i}$ is the variable of interest, computed as the average value of an explanatory variable by regime and region (also calculated as a ratio of the individual country data relative to the United States); and $u$ is an error term. Specifically, the explanatory variable $x_{i}$ includes gross trade volume, terms of trade (the exchange rate), investment, government expenditures, inflation (growth of the household consumption price level), and market orientation (the share of countries in the region determined to be "open" according to Wacziarg and Welch, 2008, as constructed in Buera, Monge-Naranjo, and Primiceri, 2011, respectively). 


\section{Figure 3}

\section{Relative Growth Regimes by Region}
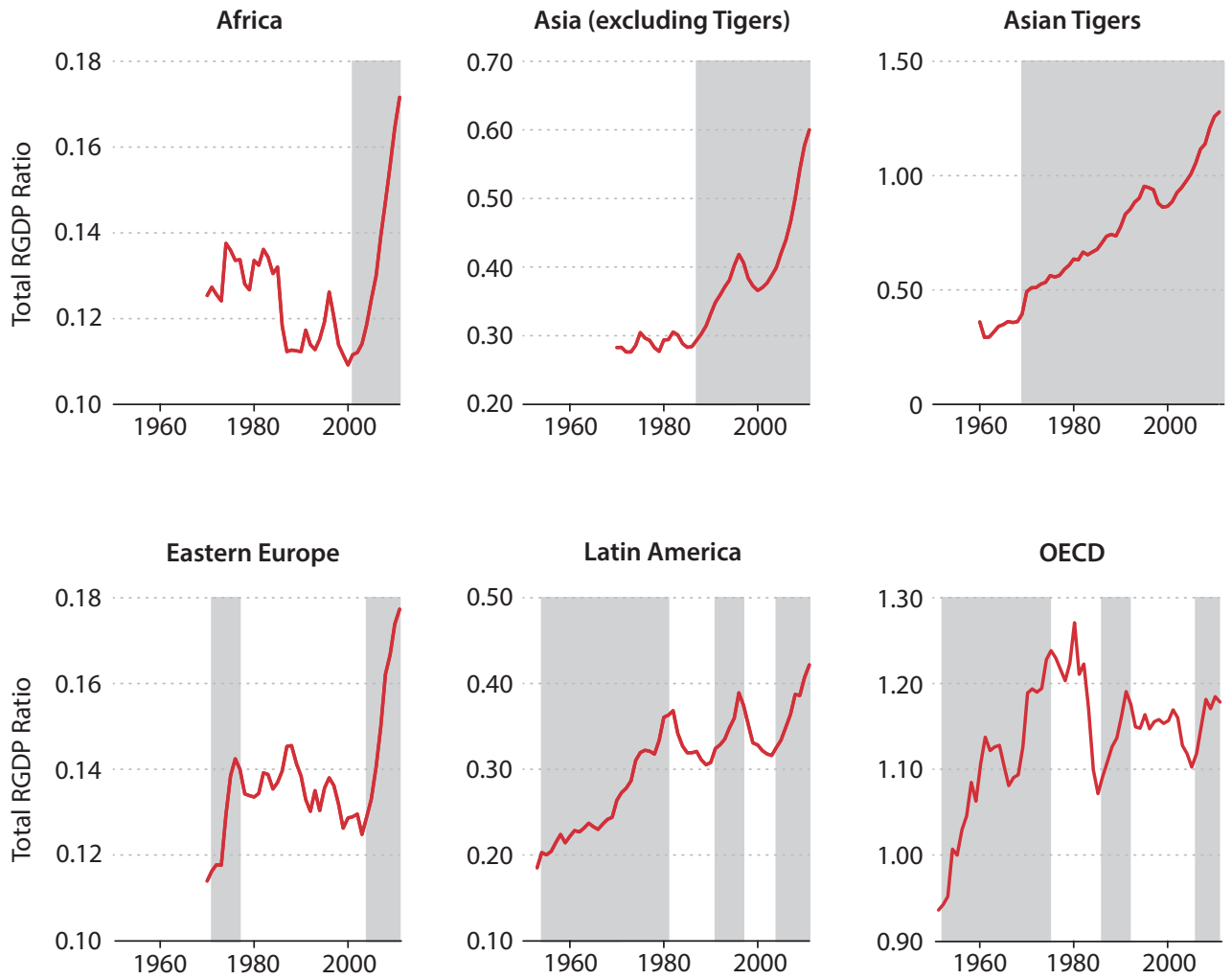

NOTE: The shaded bars indicate recessions as determined by the National Bureau of Economic Research. RGDP, real gross domestic product.

SOURCE: PWT 8.0 and authors' calculations.

The results summarized in Table 2 show that relative strength in trade, investment, and market orientation has a statistically significant relationship to strength in relative income growth rates across regimes, while that of consumer price inflation is negative and marginally significant. This analysis shows that strong economic growth relative to the United States is associated with a region's relative strength in trade, investment, or market orientation but is not associated with the exchange rate or government expenditures.

\section{INCOME TRANSITIONS: ARE THE TRAPS REAL?}

To determine the validity of our hypothesis about low- and middle-income traps, we study the historical evidence of transitions between income groups in our sample by calculating transition probability matrixes in the spirit of Im and Rosenblatt (2013). Assuming that relative GDP per capita follows a first-order Markov chain, we calculate the probability of a coun- 


\section{Table 2}

\section{Regression Results}

\begin{tabular}{|c|c|c|c|c|c|c|}
\hline Independent variable & \multicolumn{6}{|c|}{ Dependent variable: average relative income } \\
\hline Gross trade & $1.22^{* * *}$ & & & & & \\
\hline Terms of trade & & 0.98 & & & & \\
\hline Investment & & & $2.17^{* * *}$ & & & \\
\hline Government expenditures & & & & -0.63 & & \\
\hline Inflation & & & & & $-0.79 *$ & \\
\hline Market orientation & & & & & & $0.68^{* * *}$ \\
\hline Constant & $-1.87^{* * *}$ & $-0.97^{* * *}$ & $-0.88^{* * *}$ & $-0.67^{*}$ & 0.19 & -0.36 \\
\hline Observations & 20 & 20 & 20 & 20 & 20 & 20 \\
\hline$R$-squared & 0.59 & 0.01 & 0.42 & 0.03 & 0.21 & 0.43 \\
\hline
\end{tabular}

try having a relative income in income range $j$ today given a relative income in income range $i$ during the previous period. So, the probability of transitioning from income group $i$ to income group $j$ can be written as

$$
p_{i j}=\operatorname{Pr}\left(s_{t}=j \mid s_{t-1}=i\right) \text {. }
$$

Given $N$ income groups, the entire matrix of transition probabilities can be written as

$$
P=\left(\begin{array}{ccc}
p_{11} & \cdots & p_{1 N} \\
\vdots & \ddots & \vdots \\
p_{N 1} & \cdots & p_{N N}
\end{array}\right)
$$

where $\sum_{j} p_{i j}=1$.

Our analysis differs from that of Im and Rosenblatt (2013) in several ways. We divide the sample into only three relative income groups: low ( $\leq 15$ percent of U.S. income), middle ( $>15$ to 50 percent of U.S. income), and high (>50 percent of U.S. income). ${ }^{10}$ Moreover, we are interested in analyzing the incidence of economies that permanently escape the relative income traps, so we calculate three transition matrixes for period intervals spanning 10 years, 20 years, and the entire sample available (30 to 61 years, depending on data available for each country) to assess the persistence of traps in the data. ${ }^{11}$

As shown in Table 3, the relative low-income trap is highly persistent: The probability of an economy remaining trapped in the low-income range is 94 percent after 10 years (Panel A), 90 percent after 20 years (Panel B), and 80 percent after the entire observational period, 30 to 


\section{Table 3}

Transition Matrixes: Entire Sample (1950-2011)

\begin{tabular}{|c|c|c|c|c|c|c|c|c|c|}
\hline & \multicolumn{3}{|c|}{ A: $10-Y e a r$ transition matrix } & \multicolumn{3}{|c|}{ B: 20 -Year transition matrix } & \multicolumn{3}{|c|}{ C: Start-to-end transition matrix } \\
\hline & 0 to $15 \%$ & 15 to $50 \%$ & $>50 \%$ & 0 to $15 \%$ & 15 to $50 \%$ & $>50 \%$ & 0 to $15 \%$ & 15 to $50 \%$ & $>50 \%$ \\
\hline 0 to $15 \%$ & 0.94 & 0.06 & 0.00 & 0.90 & 0.10 & 0.00 & 0.80 & 0.16 & 0.03 \\
\hline 15 to $50 \%$ & 0.09 & 0.80 & 0.11 & 0.14 & 0.65 & 0.21 & 0.17 & 0.47 & 0.36 \\
\hline$>50 \%$ & 0.00 & 0.03 & 0.97 & 0.00 & 0.03 & 0.97 & 0.00 & 0.00 & 1.00 \\
\hline
\end{tabular}

61 years (Panel C). Meanwhile, the effects of a relative middle-income trap are strong in the 10 -year period (with an 80 percent probability that an economy will remain in middle-income status and a 9 percent probability that it will regress to low-income status) but dissipate in the longer term. Still, Panel C shows that more than half of the economies with middle-income status at the beginning of the sample remained at or below that relative income status (with a cumulative conditional probability of 47 percent +17 percent $=64$ percent); this finding indicates that these economies had a low probability of relative income convergence to higher levels of relative income even after moderate absolute growth during the entire 30- to 61-year period.

In other words, the probability of an economy escaping the middle-income trap is 11 percent after a 10 years, 21 percent after 20 years, and 36 percent after 30 to 61 years. Also interesting to note is that countries almost never regress to low- or middle-income status once they have reached high-income status: The conditional probability of remaining at high-income status is at least 97 percent. $^{12}$

Compelled to delve into this issue even further, we broke down the country sample by region (as shown in Table 1) and repeated this exercise. We obtained interesting results that shed light on regional growth trends commonly discussed in the development literature (Table 4). For example, African nations share an extremely strong tendency to be trapped at relative low- or middle-income levels. Regardless of the length of the period under consideration, the probability of remaining trapped in the low-income range in Africa is at least 95 percent. Moreover, even for those African countries that reached the middle-income range, their historical chance of moving further up to the high-income range is zero, while their chance of regressing to the low-income range is higher as the time period expands, reaching 40 percent at the end of the full sample.

Most Asian countries (excluding the Tigers and China and Japan) experienced similar trends. Namely, the low-income trap is extremely stable-so much so that countries can at most only temporarily escape from it. The probability of returning to the low-income range is 100 percent in the long run. The exception here is the Asian Tigers, which have been able to converge to the rich economies, transitioning into-and maintaining-a higher relative income. ${ }^{13}$

The results for Eastern European countries are strikingly different: They show a remarkably stable middle-income trap. Countries that started in the relative low-income range have 


\section{Table 4}

Transition Matrixes by Region (1950-2011)

\begin{tabular}{|c|c|c|c|c|c|c|c|c|c|}
\hline & \multicolumn{3}{|c|}{ A: $10-Y e a r$ transition matrix } & \multicolumn{3}{|c|}{ B: $20-Y e a r$ transition matrix } & \multicolumn{3}{|c|}{ C: Start-to-end transition matrix } \\
\hline & 0 to $15 \%$ & 15 to $50 \%$ & $>50 \%$ & 0 to $15 \%$ & 15 to $50 \%$ & $>50 \%$ & 0 to $15 \%$ & 15 to $50 \%$ & $>50 \%$ \\
\hline \multicolumn{10}{|l|}{ Africa } \\
\hline 0 to $15 \%$ & 0.98 & 0.02 & 0.00 & 0.97 & 0.03 & 0.00 & 0.95 & 0.05 & 0.00 \\
\hline 15 to $50 \%$ & 0.16 & 0.84 & 0.00 & 0.27 & 0.73 & 0.00 & 0.40 & 0.60 & 0.00 \\
\hline$>50 \%$ & NA & NA & NA & NA & NA & NA & NA & NA & NA \\
\hline \multicolumn{10}{|c|}{ Asia (excluding Tigers) } \\
\hline 0 to $15 \%$ & 0.96 & 0.04 & 0.00 & 0.91 & 0.09 & 0.00 & 0.83 & 0.17 & 0.00 \\
\hline 15 to $50 \%$ & 0.17 & 0.83 & 0.00 & 0.31 & 0.69 & 0.00 & 1.00 & 0.00 & 0.00 \\
\hline$>50 \%$ & NA & NA & NA & NA & NA & NA & NA & NA & NA \\
\hline \multicolumn{10}{|c|}{ Asian Tigers } \\
\hline 0 to $15 \%$ & 0.73 & 0.27 & 0.00 & 0.49 & 0.51 & 0.00 & 0.00 & 0.33 & 0.67 \\
\hline 15 to $50 \%$ & 0.00 & 0.57 & 0.43 & 0.00 & 0.15 & 0.85 & 0.00 & 0.00 & 1.00 \\
\hline$>50 \%$ & 0.00 & 0.00 & 1.00 & 0.00 & 0.00 & 1.00 & NA & NA & NA \\
\hline \multicolumn{10}{|c|}{ Eastern Europe } \\
\hline 0 to $15 \%$ & 0.50 & 0.50 & 0.00 & 0.05 & 0.95 & 0.00 & 0.00 & 1.00 & 0.00 \\
\hline 15 to $50 \%$ & 0.05 & 0.95 & 0.00 & 0.12 & 0.88 & 0.00 & 0.00 & 1.00 & 0.00 \\
\hline$>50 \%$ & NA & NA & NA & NA & NA & NA & NA & NA & NA \\
\hline \multicolumn{10}{|c|}{ Latin America } \\
\hline 0 to $15 \%$ & 0.84 & 0.16 & 0.00 & 0.77 & 0.23 & 0.00 & 0.50 & 0.50 & 0.00 \\
\hline 15 to $50 \%$ & 0.13 & 0.85 & 0.02 & 0.20 & 0.77 & 0.03 & 0.23 & 0.77 & 0.00 \\
\hline$>50 \%$ & 0.00 & 0.90 & 0.10 & 0.00 & 1.00 & 0.00 & NA & NA & NA \\
\hline \multicolumn{10}{|l|}{ OECD } \\
\hline 0 to $15 \%$ & NA & NA & NA & NA & NA & NA & NA & NA & NA \\
\hline 15 to $50 \%$ & 0.00 & 0.63 & 0.37 & 0.00 & 0.44 & 0.56 & 0.00 & 0.00 & 1.00 \\
\hline$>50 \%$ & 0.00 & 0.01 & 0.99 & 0.00 & 0.00 & 1.00 & 0.00 & 0.00 & 1.00 \\
\hline
\end{tabular}

a 50 percent probability of moving up to middle-income status in 10 years, and this probability increases to 95 percent in 20 years and 100 percent at the end of the full sample. On the other hand, countries that started in the relative middle-income range have zero probability of escaping the middle-income trap if we do not consider the chance of regressing to the lowincome range.

The results for Latin America show a trend similar to the Eastern European countries: They exhibit a highly stable middle-income trap. However, while all Eastern European nations have been successful in escaping the low-income trap in the long term, this is not true for 
Latin America, where some economies have been able to temporarily reach the relative highincome range but have not been able to maintain it.

The OECD countries show a clear tendency to move up the income ladder even if they start at a relatively lower income level. In the long run, all OECD countries become highincome nations.

Our analysis shows that (i) the relative income trap is a useful concept and (ii) the stability of low- and middle-income traps is region dependent. When we group all countries together, the relative middle-income trap does not seem very stable. However, once we exclude the OECD countries from the sample, the relative middle-income trap appears as stable as the relative low-income trap, in the sense that middle-income countries are not very likely to reach the relative high-income range and stay there but have a positive probability of moving down to the relative low-income range. Similarly, low-income countries have a positive probability of reaching the middle-income level, but they are not likely to reach the high-income range. In either case, it is far more likely for a low-income country to remain in the low-income range than to become a middle-income nation. Similarly, it is far more likely for a middle-income country to remain in the middle-income range than to become a poor nation again (once OECD countries are excluded from the sample).

Evidence from Latin America and Eastern Europe shows that a low-income country can become a middle-income country, but the means are unclear. Why are a low-income Latin American and an Eastern European country more likely than an African country to become middle-income countries and remain there? Why have only the Asian Tigers been able to defy the low- and middle-income traps by moving from low-income status all the way up to high-income status and remain there?

\section{Further Back in History}

We go further back in history to attempt to reveal more answers, yet the picture is not much different. Following the same methodology outlined previously, we use Maddison Project data (Bolt and Van Luiden, 2013) to calculate the income transition matrixes once more for the entire sample, though this time for relative income data between 1870 and 2010. The results substantiate our previous conclusion (with OECD countries included): The relative low-income trap is persistent even in the long run, and even though the effects dissipate over time, the probability of a country remaining in a relative middle-income trap is still substantial enough that it warrants a search for further explanations (Table 5). These results also support our hypothesis that both relative low-income and middle-income traps exist because the probability of transitioning from low-income to middle-income status is only 5 percent, and the probability of moving from middle-income to high-income status is only 18 percenteven in the very long run (140 years).

An important caveat to our findings is that the transition probability is based on statistical evidence observed in cross-country data. Such evidence overlooks the underlying processes that give rise to the income gaps and cross-country differences in such mechanisms. Hence, a positive transition probability of moving from middle-income to high-income status does not necessarily imply that each particular middle-income country will necessarily become a 


\section{Table 5}

Transition Matrixes: Entire Sample (1870-2010)

\begin{tabular}{|c|c|c|c|c|c|c|c|c|c|}
\hline & \multicolumn{3}{|c|}{ A: $10-Y e a r$ transition matrix } & \multicolumn{3}{|c|}{ B: 20 -Year transition matrix } & \multicolumn{3}{|c|}{ C: Start-to-end transition matrix } \\
\hline & 0 to $15 \%$ & 15 to $50 \%$ & $>50 \%$ & 0 to $15 \%$ & 15 to $50 \%$ & $>50 \%$ & 0 to $15 \%$ & 15 to $50 \%$ & $>50 \%$ \\
\hline 0 to $15 \%$ & 0.94 & 0.06 & 0.00 & 0.92 & 0.08 & 0.00 & 0.93 & 0.05 & 0.02 \\
\hline 15 to $50 \%$ & 0.08 & 0.83 & 0.09 & 0.13 & 0.75 & 0.12 & 0.31 & 0.51 & 0.18 \\
\hline$>50 \%$ & 0.00 & 0.10 & 0.90 & 0.00 & 0.12 & 0.88 & 0.00 & 0.17 & 0.83 \\
\hline
\end{tabular}

high-income country given a long enough time. In other words, even if the statistically measured transition probability is $90 \%$ or higher, it does not imply that a particular low- or middleincome country will surely become a high-income country in the long run. Hence, economic (instead of statistical) explanations of the income traps are needed.

\section{EXPLAINING INCOME TRAPS AND ECONOMIC DEVELOPMENT}

Consensus explanations for the existence of traps or the lack of rapid convergence do not exist. In this section, we first briefly review the theories that stand out, in our view, as the most prominent. We then provide some case studies to shed light on the existing theories.

\section{Existing Theories}

The general theme underlying most existing theories is that technology drives long-run growth (as Solow, 1956, points out), but there are barriers to technology spillovers and frictions in resource reallocation that prevent the adoption of new technology and innovation in low- and middle-income countries. The question is: What are these barriers?

First, as Parente and Prescott (2002) explain, a developing country's local monopoly power may impede the adoption of new technology and international capital flows. Interest groups in developing countries have little incentive to open their domestic markets and allow competition from foreign firms with more advanced technologies. There is empirical evidence to support this theory, but it does not explain why nations remain trapped at low- or middleincome levels even when they adopt policies to open domestic markets and enact radical economic reforms that lift barriers to international capital flows. In fact, many nations have encouraged the attraction of foreign direct investment (FDI) but have had little success; even if they do attract FDI, they are still unsuccessful in climbing out of the income trap. For example, Mexico adopted financial liberalization in the 1970s, accumulating a large amount of debt. But when the United States hiked interest rates in the early 1980s, Mexico suffered a debt crisis, partly because of its lack of capital controls. As another example, Russia also adopted dramatic economic and political reforms to lift capital controls starting in the early 1990s, but the result was a collapsing economy, not a reviving one.

A second popular theory to explain the income traps is the institutional theory of North $(1982,1991)$ and Acemoğlu and Robinson (2012). This theory proposes that poor nations 
fail to develop because of bad political institutions, such as a dictatorship. Under bad political institutions, the elite class builds extractive economic institutions to expropriate profits from the grassroots population. Hence, the rule of law and private property rights are not protected, and the private sector has little incentive to accumulate wealth and adopt new technologies to improve productivity. Notable examples of the institutional theory are the Eastern Europe communist countries during the postwar period before their economic reform in the late 1980s and early 1990s, as well as today's North Korea.

The institutional economists also apply this theory to explain why the Industrial Revolution took place first in late eighteenth-century England instead of in other parts of Europe. They argue that England had the best (most inclusive) political institutions in the world, thanks to the 1688 Glorious Revolution, which strengthened private property rights by restricting the British monarch's extractive power on the British economy.

However, the institutional theory's explanation of the Industrial Revolution based on the notion of better private property rights has been criticized by many prominent economic historians, such as Allen (2009), McCloskey (2010), and Pomeranz (2000). They argue that private property rights in many countries outside England, such as eighteenth-century China, were just as secure as (or even more secure than) those in England, yet the Industrial Revolution did not happen there.

Furthermore, Wen (2015) points out that the institutional theory (i) lacks explanatory power for the mechanism of China's miracle growth over the past 35 years and (ii) is highly inadequate in explaining other instances such as Russia's dismal failure to grow after the shock therapy economic reform in the1990s or South Korea's rapid growth in the 1960s and 1970s under a dictatorship. A similar case can be made for areas with identical political and economic institutions, such as the different counties within the American cities of St. Louis or Chicago, or the different parts of northern and southern Italy, where there are sharply contrasting pockets of extreme poverty and extreme wealth and areas of violent crime and obedience to the rule of law. Instead, both regional economic inequality and the failures or success stories of nations that have attempted industrialization could be explained by the specific development strategies and industrial policies adopted, rather than by the political institutions per se, as we point out later for Ireland and Mexico.

Within the neoclassical growth model framework, Lucas (2000) and Tamura (1996) claim that by adding the different rates of technology diffusion, one can explain income variation across countries. Hsieh and Klenow (2010) find that 50 to 70 percent of income differences across countries can be accounted for by variations in resource misallocations, as measured by differences in the dispersion of the marginal product of capital (MPK). Such resource misallocation reduces aggregate total factor productivity (TFP) and, hence, national income. So, low TFP (characterized largely by a misallocation of resources such as capital) signals high production inefficiencies. However, this theory is incomplete because a wide dispersion of MPK across firms can itself be the result of economic development. As the economy evolves from an agrarian society to an industrial society, the agricultural sector with nearly identical backward technologies across farm households bifurcates into a traditional rural sector and a 
modern industrial sector. Although the industrial sector has a much higher MPK than the rural sector, the overall economy is far more productive than the original backward society before the bifurcation. That is, middle-income countries tend to have a wider income dispersion than poor countries while still having higher TFP levels. The dispersion will shrink only after all sectors of the economy are fully industrialized.

Therefore, if barriers to technology spillovers exist, developing countries can still grow while failing to converge to the living standards of the developed world. The fundamental question remains: Why do these barriers exist such that advanced technologies are not rapidly adopted by developing countries? There is no consensus answer. On one hand, the institutional theory is highly inadequate because even nations that adopted radical political and economic reforms following the Washington consensus have remained stagnant for decades (such as many Latin American countries after the 1980s). On the other hand, the endogenous growth theory can hardly explain why poor nations choose not to accumulate human capital. And the dispersion theory simply describes (or measures) the outcome of the barriers of technology spillovers. Furthermore, technology is not free and is embedded in fixed tangible capital; thus, fixed investment is necessary to adopt new technologies. But investment requires savings, which are hard to accumulate when income levels are low and goods sales are limited by anarchic markets.

The implication is that policies that help create markets, attract FDI, and promote domestic saving and exports of manufactured goods are more likely to overcome the barriers of technology transfers. Based on this insight, Wen (2015) uses case studies based on China and the history of the Industrial Revolution to argue for a new stage theory (NST) of economic development, suggesting that (i) institutions are endogenous and (ii) industrialization requires the creation of a mass market to support mass production. Furthermore, the division of labor and formation of economic organizations are limited by the extent of the market (as per Smith, 1776), which in turn is extremely costly to create and can be created only sequentially through several key stages - at any of which countries can get stuck. In particular, Wen (2015) attributes both the low-income trap and the middle-income trap to government failures in market creation at critical junctures of industrialization. For example, a country will be stuck in the low-income trap when its market size is too small (or market transaction costs are too large) to spur the formation of proto-industries beyond artisan workshops. And a country will be stuck in the middle-income trap if its market size is not large enough (or market transaction costs are not low enough) to support modern heavy industries or make capital-intensive heavy industries profitable. An example that supports this theory is that of the Asian Tigers, which were able to escape both the low-income and middle-income traps because of their governments' immense help in continuous market creation to support profitable operations of laborintensive industries (in their early low-income development stage) and capital-intensive industries (in their later middle-income development stages). The NST also argues that China's growth miracle since its economic reform in 1978 has been driven not by technological adoption per se, but by government-led continuous market creation through a series of industrial policies. ${ }^{14}$ 


\section{Ireland and Mexico}

We investigate further the issue of why some countries have failed to climb the income ladder and others have succeeded by looking at the diverging cases of Ireland and Mexico. Both countries maintained a roughly similar level of development in terms of per capita income as far back as the early 1920s. However, each took dramatically different approaches to development in the postwar era, leading to different outcomes, especially after the 1980s. This occurred despite the adoption of political democracy by both nations: Mexico in 1810 and Ireland in 1921.

Ireland's economy did not experience fast growth between the 1920s and the 1950s because of anticolonial policies based on the since-discredited strategy of import substitution industrialization. ${ }^{15}$ However, since the 1950s, Ireland has used its state capacity developed in the previous period and adopted industrial policies to gradually open its borders to global markets to encourage manufacturing exports and attract FDI instead of fully liberalizing its capital markets all at once. Moreover, special government agencies were created to guide and steer such foreign investment through preferential policies (subsidies) and proper regulations to nurture its manufacturing sector. Ireland also increased government spending on infrastructure and public education for all and adopted new tax, fiscal, and monetary policies to control high government deficits and inflation. In addition, it promoted domestic investment and targeted its exports to Europe and the United States. ${ }^{16}$

On the other hand, Mexico had a far more open economy than Ireland between the 1920s and 1970s but lacked sufficient government discipline to develop its state capacity to steer the economy. Mexico's exposure to international oil markets as an oil exporter, as well as the rapid expansion of public debt in the 1970s, made its economy susceptible to more-liquid short-term capital flows instead of longer-term foreign investment. Its large government debt became very expensive after U.S. interest rates were increased drastically to curb inflation, pushing the Mexican economy into default and prompting a large currency devaluation. Moreover, Mexico did not invest highly in education, nor did it establish government agencies to design industrial policies to promote both foreign and domestic investment in areas consistent with Mexico's comparative advantages. Economic reform and nationalization of the banking system in the early 1980s prompted investors to look for financing outside the banking system, thereby changing the financial landscape and failing to stimulate industrial growth that would invigorate the economy. ${ }^{17}$

Comparing the divergent growth paths of Mexico and Ireland in the twentieth century suggests that state capacity and proper industrial policies are critical in explaining the issue, rather than differences in political institutions or vast interests of local monopolies per se. Contrary to what the Solow growth model suggests, technology is embedded in tangible capital, which is most likely to originate from the manufacturing sector instead of the agricultural and natural resource sector or services sector. Hence, advanced technology flows only from developed nations to developing nations through costly fixed investment in manufacturing. Financial capital investors from developed countries are typically interested in short-term capital gains (especially in real estate and natural resources), not necessarily in the foreign 
country's long-term development. Such types of capital flows should be controlled or regulated-instead of encouraged or unchecked-by the governments of developing countries. Thus, those countries that can find ways to grow their manufacturing sector through continuous market creation, investment, and exports are more capable of achieving technological and income convergence to the technology frontier.

\section{CONCLUSION}

In this article, we examine relative low- and middle-income traps, which we define as situations in which income levels relative to the United States remain constantly low with no clear sign of convergence. This perspective is important because even the poorest economies continue to grow at some positive rate each year; but unless lower-income economies persistently grow at a rate faster than the developed economies, they will not be able to catch up.

We show that the relative low-income trap is more persistent over time than the relative middle-income trap, though the stability of both traps is region-dependent. The cases of Latin America and Eastern Europe are proof that low-income economies can successfully escape the relative low-income trap. In particular, Latin American countries must have escaped the poverty trap before the 1900s since most were at a middle-income range (relative to the United States) at that point, but the means of achieving this level remain unknown.

To this effect, we point out challenges to the benchmark neoclassical growth theory, which predicts convergence to the developed world over time: Even in the very long run, the relative income traps and the issue of nonconvergence are prevalent. Furthermore, we discuss existing theories with the potential to explain income traps. We note two things: (i) To adopt modern efficient technologies available in developed nations, the developing nations must first create the necessary market (including the supply chains and goods distribution networks) to render such production technologies profitable. (ii) Technologies are embedded in capital, so large and continuous capital investments are required to adopt frontier technologies from advanced countries, and such investment requires large and continuous savings. Hence, creating a modern mass market is extremely costly and time consuming and thus needs to be created in steps. Therefore, industrial policies designed to help create domestic and international markets for domestic firms and attract foreign direct investment while promoting domestic investment, savings, and exports of manufactured goods are more likely to overcome the barriers of technology adoptions and transfers. 


\section{Arias and Wen}

\section{NOTES}

1 These data are from Table 2.8.2 of the World Bank's October 2015 update of the World Development Indicators. The absolute poverty line is defined as the international equivalent of the purchasing power parity of \$2 (PPP\$2).

2 In addition, the "iron law of convergence" suggests that poor countries can constantly reduce their income gap with the frontier economies by half every 35 years (see, e.g., Barro, 2015).

3 Per capita income in 2014 was about \$54,500 in the United States, \$725 in Uganda, \$650 in Afghanistan, \$437 in the Democratic Republic of the Congo, \$380 in the Central African Republic, and \$336 in Burundi, for example.

4 The term "middle-income trap" was first used by Gill and Kharas (2007) in reference to countries that have maintained a middle-income status for decades but have failed to reach a high-income status. This concept has become increasingly relevant in the face of slower economic growth seen in the developing world.

5 We review the institutional theories of development traps in a later section.

6 Cited in Pintus and Wen (2010, p. 6).

7 We exclude countries with a population smaller than 1 million and those with fewer than 30 observations. We exclude Middle Eastern countries from the analysis given that most countries in the sample are oil-rich countries with specific idiosyncrasies about their relative income that are unique to the region.

8 Even though the United States was not the richest country during the 1870s, its income per capita was more than 75 percent that of Great Britain, so it was still a good representative of the developed world. Real GDP per capita in the United States surpassed that of Great Britain in 1904.

9 Relative per capita income in 2011 was 18.9 percent in China and 8.4 percent in India.

${ }^{10}$ As in other studies, the income group thresholds are arbitrary. Therefore, we performed a sensitivity analysis to check the robustness of the results by changing the low-to-middle and middle-to-high thresholds and found that our results did not change significantly.

${ }^{11}$ A common criticism in the literature is that using long-term average growth is an inadequate approach to determine if an economy is caught in (or will be able to avoid) an income trap. However, our focus is on the changes, if any, to another (higher or lower) income group in the long term.

12 Since we compute the transition matrixes using statistical procedures and past data, the observations reflect cases of countries that have escaped the traps. However, this does not mean that the measure shown is the probability for each country to escape the trap, as some countries may remain trapped forever.

${ }^{13}$ China and Japan are included in the Asian Tigers group, explaining the 33 percent probability of transitioning from the lower to the middle relative income group in Panel $\mathrm{C}$ of Table 4.

${ }^{14}$ Although Wen's (2015) NST connects both the low- and the middle-income traps to developmental stages and reveals economic mechanisms behind the Industrial Revolution itself, theoretical models built on Wen's NST are still lacking. Models proposed to explain the Industrial Revolution are abundant, such as those of Desmet and Parente (2012), Hansen and Prescott (2002), Stokey (2001), and Yang and Zhu (2013), among others. However, such neoclassical growth models of the Industrial Revolution still fall short in differentiating and explaining the low- and middle-income traps, despite claiming to explain the Industrial Revolution based on the assumption of exogenous technological changes in the agricultural and industrial sectors.

15 Import substitution industrialization (ISI) is a trade and economic policy that advocates replacing foreign imports with domestic production, especially in manufactured goods. ISI has been advocated since the eighteenth century by economists such as Friedrich List and Alexander Hamilton. ISI policies became popular after World War II among socialist countries and Latin American nations with the intention of producing development and self-sufficiency through the creation of an internal market. ISI works by having the state lead economic development through nationalization, subsidization of vital industries (mostly heavy industries), increased taxation, and highly protectionist trade policies. ISI was gradually abandoned by developing countries in the 1980s and 1990s because of its failure to promote persistent growth and the insistence of the International Monetary Fund and World Bank on their structural adjustment programs of market-driven liberalization. For more details, see https://en.wikipedia.org/wiki/Import_substitution_industrialization.

${ }^{16}$ For a report on Ireland's development process, see Dorgan (2006).

17 See Hernández-Murillo (2007). 


\section{REFERENCES}

Acemoğlu, Daron and Robinson, James A. Why Nations Fail: The Origins of Power, Prosperity, and Poverty. New York: Crown Publishers, 2012.

Aiyar, Shekhar; Duval, Romain; Puy, Damien; Wu, Yiqun and Zhang, Longmei. "Growth Slowdowns and the MiddleIncome Trap." Working Paper No. WP/13/71, International Monetary Fund, March 2013;

https://www.imf.org/external/pubs/ft/wp/2013/wp1371.pdf.

Allen, Robert C. The British Industrial Revolution in Global Perspective. New York: Cambridge University Press, 2009.

Barro, Robert J. "Convergence and Modernization." Economic Journal, June 2015, 125(585), pp. 911-42.

Bolt, Jutta and Van Zanden, Jan L. "The Maddison Project: The First Update of the Maddison Project Re-Estimating Growth Before 1820." Maddison-Project Working Paper WP-4, January 2013; http://www.ggdc.net/maddison/maddison-project/publications/wp4.pdf.

Buera, Francisco J.; Monge-Naranjo, Alexander and Primiceri, Giorgio E. "Learning the Wealth of Nations." Econometrica, January 2011, 79(1), pp. 1-45.

Desmet, Klaus and Parente, Stephen L. "The Evolution of Markets and the Revolution of Industry: A Unified Theory of Growth." Journal of Economic Growth, September 2012, 17(3), pp. 205-34.

Dorgan, Sean. "How Ireland Became the Celtic Tiger." Backgrounder (blog), Heritage Foundation, June 23, 2006; http://www.heritage.org/research/worldwidefreedom/bg1945.cfm.

Easterly, William. "Reliving the 1950s: The Big Push, Poverty Traps, and Takeoffs in Economic Development." Journal of Economic Growth, December 2006, 11(4), pp. 289-318.

Eichengreen, Barry; Park, Donghyun and Shin, Kwanho. "When Fast-Growing Economies Slow Down: International Evidence and Implication for China." Asian Economic Papers, Winter/Spring 2012, 11(1), pp. 42-87.

Eichengreen, Barry; Park, Donghyun and Shin, Kwanho. "Growth Slowdowns Redux: New Evidence on the MiddleIncome Trap." NBER Working Paper No. 18673, National Bureau of Economic Research, January 2013; http://www.nber.org/papers/w18673.pdf.

Felipe, Jesus. "Tracking the Middle-Income Trap: What Is it, Who Is in It, and Why? Part 1." ADB Economics Working Paper Series No. 306, Asian Development Bank, March 2012; http://www.adb.org/sites/default/files/publication/29804/economics-wp-306.pdf.

Gill, Indermit and Kharas, Homi. An East Asian Renaissance: Ideas for Economic Growth. Washington, DC: The World Bank, 2007.

Hansen, Gary D. and Prescott, Edward C. "Malthus to Solow." American Economic Review, September 2002, 92(4), pp. 1205-17.

Hausmann, Ricardo; Pritchett, Lant and Rodrik, Dani. "Growth Accelerations." Journal of Economic Growth, December 2005, 10(4), pp. 303-29.

Hernández-Murillo, Rubén. "Experiments in Financial Liberalization: The Mexican Banking Sector." Federal Reserve Bank of St. Louis Review, September/October 2007, 89(5), pp. 415-32;

https://www.research.stlouisfed.org/publications/review/07/09/HernandezMurillo.pdf.

Hsieh, Chang-Tai and Klenow, Peter J. "Development Accounting." American Economic Journal: Macroeconomics, January 2010, 2(1), pp. 207-23.

Im, Fernando G. and Rosenblatt, David. "Middle-Income Traps: A Conceptual and Empirical Survey." Policy Research Working Paper No. 6594, World Bank, September 2013; http://www-wds.worldbank.org/external/default/WDSContentServer/WDSP/IB/2013/09/09/000158349_ 20130909085739/Rendered/PDF/WPS6594.pdf.

Jones, Benjamin F. and Olken, Benjamin A. "The Anatomy of Start-Stop Growth." Review of Economics and Statistics, August 2008, 90(3), pp. 582-87.

Kar, Sabyasachi; Pritchett, Lant; Raihan, Selim and Sen, Kunal. "Looking for a Break: Identifying Transitions in Growth Regimes." Journal of Macroeconomics, October 2013, 38(Part B), pp. 151-66. 


\section{Arias and Wen}

Lucas, Robert E. "Some Macroeconomics for the 21st Century." Journal of Economic Perspectives, Winter 2000, 14(1), pp. 159-68.

Luttmer, E. "Neighbors as Negatives: Relative Earnings and Well-Being." Quarterly Journal of Economics, August 2005, 120(3), pp. 963-1002.

McCloskey, Deirdre N. Bourgeois Dignity: Why Economics Can't Explain the Modern World. Chicago: University of Chicago Press, 2010.

North, Douglass C. Structure and Change in Economic History. New York: Norton, 1982.

North, Douglass C. “Institutions." Journal of Economic Perspectives, Winter 1991, 5(1), pp. 97-112.

Parente, Stephen L. and Prescott, Edward C. Barriers to Riches. Cambridge, MA: MIT Press, 2002.

Pintus, Patrick A. and Wen, Yi. "Leveraged Borrowing and Boom-Bust Cycles." Working Paper No. 2010-027C, Federal Reserve Bank of St. Louis, August 2010, revised April 2012; https://research.stlouisfed.org/wp/2010/2010-027.pdf.

Pomeranz, Kenneth. The Great Divergence: China, Europe, and the Making of the Modern World Economy. Princeton, NJ: Princeton University Press, 2000.

Sachs, Jeffrey D. and Warner, Andrew M. "Economic Reform and the Process of Global Integration." Brookings Papers on Economic Activity, July 1995, 1995(1), pp. 1-118.

Smith, Adam. An Inquiry into the Nature and Causes of the Wealth of Nations. London: Strahan and Cadell, 1776.

Solow, Robert M. "A Contribution to the Theory of Economic Growth." Quarterly Journal of Economics, February 1956, 70(1), pp. 65-94.

Stokey, Nancy L. "A Quantitative Model of the British Industrial Revolution, 1780-1850." Carnegie-Rochester Conference Series on Public Policy, 2001, 55(1), pp. 55-109.

Tamura, Robert. "From Decay to Growth: A Demographic Transition to Economic Growth." Journal of Economic Dynamics and Control, June-July 1996, 20(6-7), pp. 1237-62.

Wacziarg, Romain and Welch, Karen H. "Trade Liberalization and Growth: New Evidence." World Bank Economic Review, June 2008, 22(2), pp. 187-231.

Wen, Yi. "The Making of an Economic Superpower-Unlocking China's Secret of Rapid Industrialization." Working Paper No. 2015-006B, Federal Reserve Bank of St. Louis, June 2015;

https://research.stlouisfed.org/wp/2015/2015-006.pdf.

Yang, Dennis T. and Zhu, Xiaodong. "Modernization of Agriculture and Long-Term Growth." Journal of Monetary Economics, April 2013, 60(3), pp. 367-382. 